\title{
The historic towns of Saudi Arabia's Red Sea Coast: \\ Tourism Development and Conservation
}

\author{
Dr Aylin Orbaşlı
}

Orbaşlı, A. (2017) 'The Historic Towns of Saudi Arabia's Red Sea Coast: tourism development and conservation' in Human Interaction with the Environment in the Red Sea (ed. D.A. Agius et. al.), Leiden, Brill, 207-227

\begin{abstract}
This aim of this paper is to evaluate the position for the conservation traditional settlements in conjunction with tourism development in Saudi Arabia. The paper starts by identifying the processes of change that have lead to the gradual decay and ultimate abandonment of many historic settlements on of Saudi Arabia's Red Sea coast. In seeking solutions for their protection, conservation and revitalisation, tourism emerges as a new vehicle that could regenerate historic urban quarters. Various options are discussed in light of the significant levels of decay and abandonment, local disengagement with tangible aspects of cultural heritage and the social norms that dictate tourism practices in the Kingdom. In conclusion options beyond tourism, and ways in which 'life' can be injected into historic settlements are discussed.
\end{abstract}

Key words: traditional settlements, urban conservation, tourism, Saudi Arabia

\section{Introduction}

Like much of the rich and diverse vernacular architecture of Saudi Arabia, the historic towns of the Red Sea Coast, many of them the product of various cultural influences, are in serious danger of being lost forever. Lack of maintenance, insensitive interventions and development pressures and the abandonment of entire historic districts has become a common occurrence across the wider region. Since the 1950s a new era of wealth following the exploitation of the region's oil resources amongst other factors has led to the decline and wholesale abandonment of most traditional settlements across the Kingdom. 
Meanwhile the rich and diverse cultural heritage of the region, including historic towns, is being recognised as a significant component within Saudi Arabia's burgeoning tourism development programme. ${ }^{1}$ This in turn is opening up new opportunities to revitalise some historic settlements in coastal regions through linked tourism initiatives. Tourism and cultural heritage, though increasingly linked in urban conservation discourse and practice are not necessarily mutually compatible.

This paper evaluates how tourism can play a role in the conservation of a unique architectural heritage and the regeneration of historic urban quarters, which have been abandoned. The aim is to acknowledge the challenges facing conservation and the development of tourism in a unique set of circumstances including significant levels of decay and abandonment, local disengagement with tangible aspects of cultural heritage and social norms that dictate tourism practices.

The paper is based on research, in-depth field work and on-site observations most of the coastal and inland historic towns of the Red Sea Coast undertaken between 2002 and $2008 .^{2}$

\section{The architectural heritage of the Red Sea Coast}

The incredibly rich seafaring and trading history of the Red Sea is reflected in the equally rich architectural heritage of its once bustling trading ports on both its long coasts.

Alongside the archaeological sites attesting to the antiquity of the maritime routes are the still surviving settlements that were developed as fishing and trading ports. On the Arabian coast, the prevailing trade winds dictated trade not only with African ports such as Suakin, but also with India and beyond. ${ }^{3}$ Jeddah flourished as an important entrepôt for much of

\footnotetext{
${ }^{1}$ Supreme Commission for Tourism, Kingdom of Saudi Arabia National Tourism Plan, 2002.

2 Regional Tourism Development Plans for the provinces of Tabuk, Makkah and Jizan (2002-04) and the Red Sea Coastal Zone Plan (2005) for the Supreme Commission for Tourism. Tourism development plans for the four historic towns of Duba, Al Wajh, Umluj and Yanbu Al-Bahr (2006-08) for the Royal Commission for Yanbu and Jubail.

${ }^{3}$ William Facey, 'Queen of the India Trade' Saudi Aramco World, 56, 6 (Nov/Dec 2005) (available at: http://www.saudiaramcoworld.com/issue/200506/queen.of.the.india.trade.htm)
} 
this trading activity as well as the gateway to Makkah and Madinah, the two holiest cities of the Islamic world. Many other settlements of various sizes have populated the Arabian Red Sea coast from Haql on the Gulf of Aqaba in the north, down to Jizan and the Farasan islands to the south. Many were trading or fishing ports with important links to inland oases and dessert trade routes.

The buildings in most of these settlements, as those of Jeddah, are built out of coral stone layered with horizontal timber supports and adorned with intricate timberwork balconies and projections, locally known as $r \overline{\boldsymbol{0}}$ shan. In Jeddah the tightly formed one square kilometre centre densely populated with five to six storey houses with ornate timber projections, plasterwork walls and in places neo-classical interiors has exceptionally survived and was designated a UNESCO World Heritage Site in 2014. In many of the other settlements too, the architecture is noteworthy and often a unique variation on the regional style of massing of closed, open and semi-open spaces, and timberwork details that are not dissimilar to examples on the African Red Sea Coast. ${ }^{4}$ Coastal influences are clearly evident, whereby the architecture of Duba shares greater similarities with Quseir Egypt as Yanbu Al-Bahr does with Suakin in Sudan (Figure 1a). In the Farasan Islands, on the other hand, plasterwork skills of Indian craftsmen combine with local motifs in the decoration of houses (Figure 1b).

While encompassing the stipulations of Islamic tradition and community values, settlement form has been determined by the size and geographic characteristics of a place. Al Naim describes the transformation of traditional Saudi society from small, scattered settlements to well-connected and networked urban centres. In the latter phases, the (historic) city became a dynamic place of change, where private and semi-private culs-de-sac would appear and disappear as family structures and consequently house divisions changed. ${ }^{5}$ This

\footnotetext{
4 Jean-Pierre Greenlaw, The Coral Buildings of Suakin (Stocksfield: Oriel Press, 1976).

${ }^{5}$ M.A. Al Naim, The Home Environment in Saudi Arabia and Gulf States: Growth of Identity Crises and Origin of Identity. CRiSSMA Working Paper No 10-2006, volumes 1 and 2 (Milano: I.S.U.
}

Università Catolica, 2006) 
pattern was also conducive to social interaction. ${ }^{6}$ The settlement patterns of the coastal towns have similar characteristics, often combining the tight knit neighbourhood pattern of an Islamic city with the functions of a trading port or fishing harbour. Depending on the size of the settlement and importance of the port, the waterfronts were often populated with the larger merchants' houses, warehouses, customs buildings and fortification structures.

Considerable documentation of this rich and diverse legacy of architectural heritage has been undertaken by both Saudi and international scholars, some of which provide the only evidence of certain types and styles. ${ }^{7}$ The work undertaken by Geoffrey King in the 1980s and published in 1997 remains one of the key sources in English on the regional traditional building techniques of the Kingdom, including of the Red Sea Coast. ${ }^{8}$ These various studies not only record the heritage that has already been lost, but also highlight the considerable task that lays ahead to conserve what does remain.

\section{Abandonment and change}

Since the 1950s and especially in the post-1974 era, oil-fuelled wealth has not only brought rapid urbanisation to Saudi Arabia, but it has also resulted in the abandonment of traditional building forms in both urban and rural areas. The developments in Saudi Arabia are symptomatic of what is happening in the wider region, where a sudden and pronounced change in lifestyle within one generation has brought with it a sudden and often irreversible loss of traditional buildings. While many social traditions are strongly upheld in the Kingdom, the traditional architecture is no longer able to service the demands of a modern technology-savvy consumer society. As historic quarters have been abandoned and, in places, temporarily inhabited by immigrant workers, they have also become associated by many with being 'backward' or considered as slum areas.

\footnotetext{
${ }^{6}$ M.A. Al Nowaiser, "Traditional and Modern Settlements in Saudi Arabia" in Habitat International, 9, 1 (1985), 5-17 argues that the features that promoted social interaction have disappeared from new settlements, where the new patterns also influence societal behaviour.

${ }^{7}$ The Haj Research Institute for example was instrumental in recording the old houses of Makkah prior to their demolition.

8 Geoffrey King, The Traditional Architecture of Saudi Arabia (London: I.B.Tauris, 1998).
} 
Fundamentally, the traditional architecture in Saudi Arabia is a building form that has become largely redundant for the lifestyle of contemporary Arab society. Most of the residential stock that is over 50 years old is no longer suited to modern lifestyles. The unglazed windows or rudimentary sanitary facilities no longer fit well with contemporary living standards. Even in many of the traditional shopping streets (souq) the units are often too small and lack ancillary facilities and storage space required for modern retail practices. Finding new uses for a large stock of redundant buildings often built with low grade materials that are now in a very poor condition and lacking in services and infrastructure, is a major challenge.

Of most significant concern is the size of the stock and its poor state of repair following years of neglect and exposure to harsh climatic conditions. The predominance of building materials susceptible to rapid decay, such as mud brick and palm trunks, has increased the vulnerability of the buildings to weathering. Even though coral is more resilient than mud brick, it is still considerably less durable than most other types of stone and more so once protective renders have been lost. ${ }^{9}$ Most traditional structures lack basic amenities such as indoor bathrooms and running water. Where older buildings have been modernised, new services can also further damage the historic fabric through water leakage. The use of incompatible new materials such as concrete, on the other hand, can also cause damage by placing undue loads on fragile structures and by compromising the breathability of natural materials. ${ }^{10}$ Nonetheless, early abandonment has also ensured that some buildings maintain almost all their original features and have been spared from later additions such as water tanks or corrugated iron roofs. (Figure 2)

Much of King's's research was undertaken in the 1980s and there is a noticeable level of loss and decay between that time and our site visits undertaken between 2001 and 2005. At the same time there is a surprising level of survival, given that there has been almost no

\footnotetext{
${ }^{9}$ Aylin Orbaşli, "The Conservation of Coral Buildings on Saudi Arabia's Northern Red Sea Coast", Journal of Architectural Conservation15, 1 (2009): 49-64.

$10 \mathrm{lbid}$.

${ }^{11}$ King, Traditional Architecture of Saudi Arabia
} 
maintenance or conservation in the intervening period. Across the Red Sea coast it has often been the case that the modern city has circumvented and grown around the old town. The historic centre of Jeddah, Al Balad, where development pressures have been greatest, concerted efforts in protection and conservation are linked to the World Heritage Site nomination. ${ }^{12}$

More notable are changes to the settings of the historic settlements as they have been cut off from their original landscape and remained isolated within the modern city that surrounds them. In some cases, this includes the loss of a link to their coastal foreshore through extensive coastal infill and port developments. This significantly affects their urban character and setting in what might be described as their 'front'; the readily recognised character and silhouette when approached by boat. The character of the settlements as they appear in the few surviving photographs taken from the sea, and the notable port buildings, such as customs houses and the grander houses of the rich merchants that formed the all-important water frontage, has thus been lost (Figure 3). In most places, including Jeddah, the once distinct city walls have also disappeared as historic quarters are merged with the growing city. At the same time the urban grain has been altered through encroachment or through the insertion of new vehicular traffic routes and road widening schemes.

Islam remains a main determinant of the Saudi way of life and its associated socio-cultural values are strongly upheld, and resistance regularly expressed to the changes westernisation could bring to social and moral habits. However, while a traditional way of life pervades in Saudi society, this is not linked to the continuity of traditional dwellings and settlements. In the physical sense modernity has severed the link people had built up with their environment for centuries. ${ }^{13}$ Western models of architecture and imported material came to symbolise prestige in the 1970s. In cities, ownership of the new detached houses, locally known as villas and furnished in the western style, became a social status symbol,

${ }^{12}$ Saudi Commission for Tourism and Antiquities, Jeddah: the Gate to Makkah World Heritage Site Management Plan (2013)

${ }^{13} \mathrm{Al}$ Naim, The Home Environment in Saudi Arabia and Gulf States: Growth of Identity Crises and Origin of /dentity. 
while traditional factors like cooling could be ignored as air conditioning became widely available. ${ }^{14}$ The advantages of modern dwellings have been fully embraced and their internal layouts adapted to Saudi customs and family structure. ${ }^{15}$ Meanwhile cities across the Kingdom are expanding on the grid plot layouts of North American suburbia, entirely car dependant and proving very little natural protection from the elements.

In evaluating the role of urban heritage in Saudi Arabia, we need also to consider the relevance of traditional architecture to contemporary Saudi society as having value, meaning and contributing to a distinct local or regional identity. Mai Yamani, discussing the continuation of local traditions as a way of expressing a distinctly Hijazi identity within the Kingdom, does not include the built or vernacular heritage of the Hijaz amongst these, even though a picture of a historic house from Yanbu Al Bahr is used to illustrate the front cover of the book. ${ }^{16}$ Unlike in neighbouring Gulf States, where some aspects of the vernacular heritage have come to be celebrated as identifiers or symbols of a national identity, ${ }^{17}$ there is limited political millage for this in Saudi Arabia where two holy mosques of global significance provide a highly recognised symbol of a shared national (Saudi)

${ }^{14}$ Al Naim, The Home Environment in Saudi Arabia and Gulf States: Growth of Identity Crises and Origin of Identity (2006) notes that there was a transitional period where the traditional style was initially adapted to new materials and forms. The introduction of governmental housing subsidies in 1975 enabled wider ownership in newly built neighbourhoods, and became a further catalyst for the wholesale abandonment of the traditional neighbourhoods.

${ }^{15}$ Houses are commonly surrounded by a high wall for privacy and have separate male and female entrances with layouts that also secure the privacy of the family from male guests. Ali Bahammam, "Factors which Influence the size of the Contemporary Dwelling: Riyadh, Saudi Arabia" in Habitat International, 22, 4 (1998) 557-570, notes that the importance of hospitality is reflected in the number and size of reception rooms. He also notes that while in the past the function of a room would have been flexible, the use of modern furniture determines the function of each space in modern dwellings.

${ }^{16}$ Mai Yamani, Cradle of Islam: The Hijaz and the Quest for an Arabian Identity (London: I.B. Tauris, 2004)

17 See for example Yasser Mahgoub, "Architecture and the Expression of Cultural Identity in Kuwait" in The Journal of Architecture 12, 2 (2007) 165-182; and R.W.Hawker, "Imagining a Bedouin Past: Stereotypes and Cultural Representation in the Contemporary United Arab Emirates" (available at http://inhouse.lau.edu.lb/bima/papers/R_W_Hawker, retrieved November 2008) 
identity. Riyadh is a rare example where the Arriyadh Development Authority, engaged in a conscious programme of developing buildings that combined tradition with modernity; ${ }^{18}$ in this case the 'traditional' inspiration being the Najdi mud brick fort style of the interior, the homeland of the ruling Al Saud family.

\section{The urban conservation paradox}

Across the Middle East and the Arab world, the rapid loss of the rich urban heritage and traditional architecture, much of it an accumulation of many centuries, civilizations and influences, under the pressure of rapid urban growth and modernisation, has been a subject of concern for several decades now. ${ }^{19}$ While cities and settlements are in a state of flux and continuously change and develop, the rate of change that has followed the developments of industrialisation and the wealth brought by the oil boom have been unprecedented. Population growth, coupled with rural to urban migration, has often rendered historic cores redundant, turned them into overpopulated slums or seen their wholesale replacement with modern new quarters. Urban conservation has rarely appeared as a government priority in the Arabian states or for many of the western master planners they employed. Ihsan Fethi has pointed out that "as a consequence of this laissez-faire attitude by most Arab municipal authorities and governments, together with general public ignorance and indifference, this unique traditional heritage has sustained great losses and is in real danger of total disappearance." ${ }^{20}$ Yet this is a distinguished heritage of urban form, architectural expression, building techniques unique to the region and in places one of exquisite craftsmanship.

Urban conservation, by definition, encompasses not only the physical but also the social fabric of an historic urban quarter or traditional settlement. Definitions of urban

\footnotetext{
${ }^{18}$ Mohammed A. Eben Saleh, "The Integration of Tradition and Modernity: A Search for an Urban and Architectural Identity in Arriyadh", Habitat International, 22, 4 (1998) 571-589.

${ }^{19}$ See for example publications by the Aga Khan Program for Islamic Architecture (Cambridge Massachusetts, 1980-1984)

20 Ihsan Fethi, "Arab Experience in Urban Conservation: The Mismanagement of Heritage as a

Cultural Resource - Some Critical Lessons",A/ Mohandis 41 (2005) 17.
} 
conservation frequently concur on it being a process of managing change within a living environment and establishing a balance between physical rehabilitation, economic development and social continuity. ${ }^{21}$ Significantly, an abandoned settlement will lack the very social fabric that holds the physical fabric together and often gives a place its distinct identity and lived-in character. In their abandoned states, many of the settlements have simply become relic landscapes. This implies that the vernacular heritage is no longer part of an ongoing tradition, but has been transformed into a heritage object that needs to be preserved, conserved and formally managed, not dissimilar to an archaeological site. This sets new challenges to how urban conservation is approached and what its end goals are.

Where there have been conservation projects, these have focused on a near-recreation of an historic environment, either serving the tourism industry or as a token gesture to heritage in the urban realm. The Arabian Gulf coast now abounds with projects where old markets have been sanitised and historic neighbourhoods rebuilt as cultural quarters devoid of life and of limited local interest. Heritage-led regeneration in the region has become a largely profit-driven endeavour that often lacks an understanding or respect for inherent heritage values, which are subsequently lost in the stylistic approaches aimed at creating tourist-friendly environments. In comparison, not only does Saudi Arabia have a much richer heritage in terms of quantity, quality and diversity, but the pressures of tourism development and the need to showcase tourism have a different dynamic than in other Arab Gulf countries. But this does not preclude it from facing a similar number of challenges.

Although there is as yet no official 'conservation area' type protection legislation in Saudi Arabia, the protection and conservation of the built heritage is managed by the Saudi Commission for Tourism and Antiquities (SCTA), and protected by Royal Decree No M/26. However, historic areas also come under the jurisdiction of local municipalities, which can designate protection zones in their urban plans. In practice though, local authorities are

\footnotetext{
${ }^{21}$ See for example Peter J. Larkham, Conservation and the City (London: Routledge, 1996); Steve Tiesdell, Taner Oc and Tim Heath, Revitalising Historic Urban Quarters (Oxford: ButterworthHeinemann, 1996).
} 
more likely to be concerned with public safety and the demolition of historic buildings that are deemed to be 'dangerous' than engage fully in the conservation of historic neighbourhoods.

To date the protection and conservation of traditional settlements in the Kingdom has predominantly focused on recording and research. ${ }^{22}$ Nonetheless the SCTA has been instrumental in developing a number of conservation initiatives across the Kingdom, ranging from works to the historic souq in Riyadh and ongoing works to present the old capital of Al Diriyah, to flagship projects in the stone tower villages of Dhi Ain and Rij Al Alma in Abha and Asir provinces respectively. The latter two projects have notably been undertaken in close collaboration with the local communities that once inhabited them. In Al Balad (Old Jeddah), collaboration with a specifically appointed conservation office has been instrumental in enabling conservation to be undertaken. This does, however, remain a race against time with only a small number of sufficiently qualified craftsmen and often very limited interest from the property owners. Historic buildings in the core historic area continue to collapse or are lost to devastating fires on a regular basis.

The loss of vernacular building skills and the scarcity of skilled craftsmen to carry out conservation remains a major constraint. The Kingdom, like many countries of the region, has become dependent on an immigrant labour force, mostly from south Asia, for construction work. In many places local craftsmen have not plied their trade for over 20 years and many skills have been forgotten and are not being passed down. ${ }^{23}$ This not only hinders conservation through a serious skills shortage, but also means a body of knowledge, fundamental to understanding traditional construction techniques and practices, is being lost. ${ }^{24}$

\footnotetext{
${ }^{22} \mathrm{~A}$ conference held in $2002(1423 \mathrm{H})$ and accompanying publication is a useful survey of the urban heritage of the Kingdom that draws together the information available in various publications. ${ }^{23}$ Aylin Orbaşli, "Training Conservation Professionals in the Middle East", Built Environment 33, 3 (2007): 307-322.

24 The Pakistani scholar Arif Hasan reports a simultaneous loss of craft skills and know-how in Pakistan as local crafts people take up more lucrative jobs in Arabia (Seminar discussion, London, April 2008)
} 
Most architects and planners in the region are trained only in the techniques and principles of new buildings and not in the rehabilitation or conservation of old buildings. ${ }^{25}$ This also includes decision makers at national and local level. In many municipalities, planners and decision makers are unlikely to be aware of the value of the heritage or what conservation good practice entails. Nonetheless, in many towns there are active societies and individuals who are keenly researching and recording the history of their town and its cultural traditions, and in places are also becoming involved in projects to restore historic buildings. In the absence of sufficient funding and necessary expertise, however, some well-intended conservation projects can also be damaging to the historic fabric and character of an area.

Furthermore, even where there is a will to conserve, the cost of repairs and ongoing maintenance thereafter can be prohibitive, particularly when there is no defined end use and if the financial return on the property value is negligible. Inheritance over two or more generations often results in a single house having as many as 100 owners, reducing any incentive for maintenance and additionally hindering the purchase of redundant buildings by third parties. ${ }^{26}$ It is quite clear that there is no discernible economic benefit for individuals to restore their historic houses, yet the private ownership of properties also discourages the authorities from taking actions should they be willing to take on their conservation.

Across Saudi Arabia vernacular heritage is at a critical point where inaction will lead to the wholesale loss of a valuable cultural asset of local, regional and international significance. Each historic settlement still holds within it evidence of traditional settlement patterns and

\footnotetext{
25 Ronald Lewcock, "Conservation in Practice" in Architectural and Urban Conservation in the Islamic World. (Geneva: Aga Khan Trust for Culture, 1990).

${ }^{26}$ Mustapha Ben Hamouche, "Manama: The Metamorphosis of an Arab Gulf City", in The Evolving Arab City, ed. Y. Elsheshtawy (London: Routledge, 2008), p.208 reports on the consequences of the traditional legal inheritance system existing side by side with modern planning regulations and the tendency for the abandonment of historic properties with the increase in the number of inheritors.
} 
morphology, architectural and craftsmanship legacies, as well as increasingly tenuous links to intangible heritage and a past way of life, customs and traditions. Although most of these settlements no longer retain social values as dwelling places, they embody cultural and educational values. While the potential for the revitalisation of historic cores and traditional settlements as living environments is limited, growing tourism interests in the region holds within it some opportunities to conserve and re-use some buildings for a number of tourism and culture related functions. The following section evaluates whether some of these values can be upheld whilst seeking an economically viable future for some of the Red Sea coastal towns through tourism.

\section{Tourism as a vehicle for urban conservation}

It is now well-established that tourism can play a vital role in the preservation of historic towns and urban quarters. The ambiance of the historic environment, the unique character of these places and the link they provide with the past are just some of the reasons that make them attractive places to visit. For many European historic towns, focused conservation practices coupled with developing attractive visitor offers has resulted in tourism becoming a major economic sector. ${ }^{27}$ Over the past two decades, the economic potential of historic towns has been recognised globally, whereby not only are development aid programmes recognising heritage as a driver of economic regeneration through tourism, but also towns councils are seeking to benefit from what is seen as a lucrative market. It is also recognised that tourism can be the instrumental carrot that is used to save historic areas from destruction and persuade political opinion to see them as an asset. Tourism in the context of historic towns is not without its challenges and problems. Increased prices, gentrification, pressures on services, cultural conflicts and loss of privacy for locals are commonly experienced and present some of the key management challenges. ${ }^{28}$ In a growing number of cases a rapid increase in visitor numbers and

\footnotetext{
${ }^{27}$ G. J.Ashworth and J. E. Tunbridge, The Tourist Historic City (London: Belhaven Books, 1990). ${ }^{28}$ Aylin Orbaşli, Tourists in Historic Towns
} 
overdependence on tourism as an economic sector is resulting in the 'musealisation' of historic towns as tourism takes over from local activity. ${ }^{29}$

Since the year 2000, Saudi Arabia has embarked on an active tourism growth programme through its National Tourism Development Plan, which also encompasses the management of the Kingdom's rich, diverse and often threatened cultural assets. ${ }^{30}$ One of the key objectives of tourism development has been to increase employment opportunities for the Kingdom's young population and to diversify the economy, with underlying concern for the preservation of the identity, traditions and way of life of Saudi society. ${ }^{31}$ In keeping with this outlook and concern, the key markets being developed are the domestic market, visitors from other Gulf Cooperation Council (GCC) countries and Muslim visitors undertaking Umrah.

Notably, the vast majority of cultural heritage assets of the Kingdom, major archaeological sites, historic towns and villages, are more likely to appeal to the Western cultural tourism markets than the key sectors identified in the National Tourism Development Plan. Although the target visitor groups may be perceived as those least likely to be interested in the cultural heritage offer, they are likely to be seeking leisure opportunities in coastal areas. The challenge can also be seen in how cultural tourism can be developed to generate opportunities that these visitor groups will engage with. ${ }^{32}$

\footnotetext{
${ }^{29}$ Anja Nelle, "Museality in the urban context: An investigation of museality and musealisation processes in three Spanish-colonial World Heritage Towns", Urban Design International, 14 (2009) 152-171.

30 Supreme Commission for Tourism, Kingdom of Saudi Arabia National Tourism Plan, 2002.

${ }^{31}$ Peter Burns, From Hajj to Hedonism? Paradoxes of Developing Tourism in the Middle East, in Tourism in the Middle East: Continuity, Change and Transformation, ed. F.R. Daher (Clevedon: Channel View, 2007) pp.215-236.

32 Michael Robinson and Melanie K. Smith, "Politics, Power and Play: The Shifting Contexts of Cultural Tourism" in Cultural Tourism in a Changing World, eds Melanie K. Smith and Michael Robinson (Clevedon: Channel View, 2006)
} 
The development of cultural tourism in Saudi Arabia, therefore, not only needs to consider ways in which it can be made attractive to this visitor group, but also to balance the demands of a visitor attraction with social sensitivities. It is fundamental that any approach to tourism development adequately fulfils the needs of visiting Saudi families as a welcoming and safe environment to visit. For example, the privacy of women will determine how public spaces and attractions are spatially and temporally organised, including provision of semi-private spaces where family groups can rest and the designing out of spaces that are seen to potentially compromise privacy. This will require an element of planning that has to be balanced with protecting the character and inherent morphology of a historic settlement.

The biggest challenge in terms of both conservation and tourism development is the scale of the problem in terms of the quantity of the historic building stock. In the Red Sea coastal zone there are not only numerous historic settlements requiring urgent attention, but within each a substantial stock of unused historic buildings of architectural merit. The scale of the problem, a yet to be established financial model, compounded by a severe shortage of craft skills, requires a strategic approach in the selection of pilot or exemplar projects and the difficult task of determining priority settlements and priority areas or projects within them. In Yanbu Al Bahr alone there are more than 300 traditional buildings that make up the abandoned historic quarter for which new tourism functions are being sought. ${ }^{33}$

One of the defining characteristic of Islamic settlements is the hierarchical division of space based on 'public' and 'private' uses, exemplified as a distinction between the noisy and bustling commercial hearts and the private and secluded residential neighbourhoods. The most appropriate tourist related uses for historic buildings in an old town would therefore be around the commercial areas such as a rejuvenated souq attracting small scale businesses and crafts, while other commercial buildings with easily adaptable plan forms might be used for functions including restaurants or cafes. This, however, would create no more than a core area where tourist functions are viable. The morphology and layout of a

\footnotetext{
${ }^{3}$ PLB Consulting and Llewelyn Davies Yeang, Yanbu Al Bahr Tourism Development Plan (2007)
} 
town can also play an important role in how areas are selected for pilot projects. In Al Wajh for example, the proximity of the old souq to the waterfront generates potential for restoration and the re-introduction of activity in conjunction with other leisure activities on the cornice. However, a limited carrying capacity for heritage tourism could mean that this would be at the expense of the restoration of a cluster of significant historic buildings including the fort set on higher ground.

The reuse of residential buildings, especially some of the more substantial ones such as the merchants' houses that were also often linked to the central commercial districts, can often also be linked to the revitalisation of a core area. In Jeddah, the restored Al Naif house is not only a museum on life in a merchant's house, but being located at the heart of the Al Balad also acts as a showcase for the work of the Old Jeddah conservation team. Other examples where historic houses are re-used for cultural uses abound in the region. In Muharraq in Bahrain for example, a group of substantial houses have been restored and converted for linked cultural functions. Similarly, in Dubai the preservation of a small pocket of historic houses in Bastakiya for similar uses was seen as a means for developing cultural tourism as an alternative to the fundamentally leisure and commerce/retail base of tourism. ${ }^{34}$

Other precedents include specialist or boutique hotels that are developed in one or a cluster of redundant buildings. These are more commonly encountered in the historic medinas of North Africa which already serve an established western tourist market. Although there are several precedents of entire (abandoned) villages being converted exclusively for tourism use, they generally serve a specific and established market. The Taibet Zaman development in Jordan for example is a semi-abandoned village that was successfully converted into a hotel complex conveniently located and predominantly serving western tourists visiting nearby Petra. Only a small number of settlements in Saudi

\footnotetext{
${ }^{34}$ H. S. Gabr, "Reflections on the historic Bastakia district in Dubai UAE" in Tourism and Heritage Relationships: Global, National and Local Perspectives, eds Mike Robinson et.al. (Gateshead: Centre for Travel and Tourism in association with Business Education Publishers, 2000) 197-210.
} 
Arabia would have suitable accommodation for a similar type of development, and even then the market demand would need to be established and a willing operator found.

While the preservation of a cluster of buildings may be achieved through tourism or culture-led approaches, given the size of some of the settlements, there will still remain a large body of traditional buildings for which meaningful new uses cannot be found. The health and safety implications of a semi-derelict settlement, combined with development pressures in urban areas, are most likely to result in a core tourism area that has been robbed of its fundamental context and character of setting. A further concern is the absence of an urban dynamic, that of a living city and the loss of context, especially when the waterfront which would also have added an attraction has been lost.

The residential quarters, with their networks of narrow streets and inward looking houses with high walls and few ground floor openings, however, is not an urban characteristic that immediately lends itself to tourist activity. The alteration of these characteristics to accommodate tourism through the assignation of new and different functions to residential units can result in the loss of the unique and fundamental character of a place. ${ }^{35}$ In both the Dubai and Muharraq, examples the private character of the neighbourhood is revoked through predominantly public uses assigned to the buildings (Figure 5). Nonetheless, the inactive frontages have impacted on the ability of these areas to become active urban areas that will render them attractive to tourists.

Critically, for many visitors, one of the key attractions of visiting a historic town is the activity and life within it. ${ }^{36} \mathrm{~A}$ historic area devoid of 'life' will inevitably project a sterile and museum or theme-park like quality. Some anthropologists consider there to be two forms

\footnotetext{
${ }^{35}$ Aylin Orbaşli, "The 'Islamic' City and Tourism: Managing Conservation and Tourism in Traditional Neighbourhoods" in Tourism in the Middle East: Continuity, Change and Transformation,ed. F. R. Daher, ed (Clevedon: Channel View, 2007) 161-187.

${ }^{36}$ See also Myriam Jansen-Verbeke, "Involving People - Bruges" in Historic Cities and Sustainable Tourism(London: ICOMOS-UK, 1995); Aylin Orbaşli, Tourism in Historic Towns, Urban Conservation and Heritage Management (London: Spon, 2000).
} 
of authenticity in tourism, the first relates to knowledge, or authenticity that can be scientifically proven and the second relates to feeling, the act of seeking authentic social relations. ${ }^{37}$ In this case it could be argued that even when careful conservation authenticity of the physical environment can be achieved, the visitor will inevitably be denied the chance of an authentic social experience. This, however, may be a small price to pay for the preservation of the region's unique heritage.

At the same time, there is a danger in the aftermath of tourism of reinventing the past and re-creating heritage as an attraction. The tourism industry in the Middle East in particular is fuelling pastiche attitudes to an imagined past, ${ }^{38}$ in what AlSayyad refers to as manufactured heritage. ${ }^{39}$ Across the region there are a growing number of hotels and resorts that are distinctly seeking a 'historic' and often vernacular style as a selling point. This not only devalues heritage, but also impacts on how what little remains of the authentic is preserved, further confirming the belief that heritage can always be reconstructed in modern materials where, when or how it is convenient.

\footnotetext{
${ }^{37}$ Tom Selwyn, The Tourist Image: Myths and Myth Making in Tourism (Chichester: John Wiley and Sons, 1996).

${ }^{38}$ Farouk Rahmi Daher, "Reconceptualising Tourism in the Middle East: Place, Heritage, Mobility and Competitiveness"in Tourism in the Middle East: Continuity, Change and Transformationed. F. R. Daher (Clevedon: Channel View, 2007) 1-69.

39 Nezzar AlSayyad, Consuming Tradition and Manufacturing Heritage: Global Norms and Urban Forms in the Age of Tourism (London: Routledge, 2001).
} 


\section{Other alternatives}

Given the size of the stock, it is inevitable that more settlement sites, especially those built out of weak materials will rapidly disappear without further intervention. However, to totally abandon or ignore this heritage would be an indication of the absence of a political will to conserve any part of this rich heritage, which is not the case.

The establishment of open-air museums, where best examples of vernacular building types can be displayed, may also be considered as a way in which examples of this unique heritage can be preserved. Such museums can also be venues for other cultural activities and the display of handicrafts. Interestingly, open air museums - a northern European invention - are enjoying a new popularity in the Arabian Gulf region through the concept of 'heritage villages' where traditional architecture and ways of life can be demonstrated. In Saudi Arabia a number of such initiatives already exists, alongside provincial and private museums that include ethnographic collections and displays of traditional room or building settings. Open air museums can be directed at both local and international visitors. For example, in the UAE the heritage village in Dubai is seen to be created for the benefit of international tourists, whereas the annual heritage festival held in Sharjah's largely rebuilt historic quarter is primarily a local event. ${ }^{40}$

An open air museum, however, will never fully capture the authenticity of a living environment or indeed the urban or landscape setting of settlements. Nonetheless, the research value of recoding and preserving key examples of rapidly disappearing heritage cannot be overlooked. Placing buildings in a managed site additionally eliminates the health and safety risks that surround abandoned and semi-abandoned sites.

On the other hand, a historic environment that is solely the product of a tourism-led approach to urban conservation and heritage protection will also lack a level of authenticity in the absence of a holistic approach that engages with local populations, even if they no

\footnotetext{
40 O.J. Picton, "Usage of the concept of culture and heritage in the United Arab Emirates - an analysis of Sharjah heritage area" Journal of Heritage Tourism. 5, 1 (2010) pp. 69-84.
} 
longer reside in these areas. At its most pertinent the result will be a designated and managed 'quarter' of designated leisure activity. Contrary to urban and rural regeneration projects in other parts of the world, where the local community as stakeholders are pivotal to the process, the key challenge in Saudi Arabia is to consider how, and if, 'life' can be brought back into abandoned areas. Consequently it will never be regeneration in the fullest sense but a matter of importing life back into settlements, some of which are of considerable size.

Local engagement with the process must therefore be an important component of any approach. Since most traditionally built houses are no longer suitable for the present day living needs of Saudi families, re-establishing a residential critical mass in the historic town is neither likely nor realistic. But short term or seasonal uses should not be precluded. Sensitive infill projects and effective use of periphery areas where vehicular access, car parking and servicing might be more viable can help build up a critical mass of activity and use. This is not necessarily just through conservation or the repetition of styles but as Saleh argues through the utilisation of more traditional processes in architecture and planning that can help in maintaining a sense of continuity and tradition. ${ }^{41}$

The growth of a second homes market, where locals are encouraged to restore family properties or to purchase traditional houses for weekend use or as a venue to entertain in the traditional way could help achieve a critical mass that would also support the tourism and cultural functions. While the authenticity of such approaches might be questioned, it is not that different from the current situation in numerous Mediterranean villages.

Generating awareness and interest in the built heritage, however, remains a major challenge. Only a very small proportion of the population with resources and potential interest is even aware of the wealth or existence of the vernacular heritage. Whilst building awareness and understanding of conservation amongst decision makers is an important first step, a much bigger challenge lies in convincing the local population of the value of

\footnotetext{
${ }^{41}$ Mohammed Abdullah Eben Saleh, "The Integration of Tradition and Modernity: A Search for an Urban and Architectural Identity in Arriyadh" Habitat International, 22, 4 (1998) p. 574.
} 
this heritage and encouraging them to take an active part in its renovation and re-use, as owners, users or as visitors. Like many studies have found, the dedication of a local community to a project is more likely to be successful than wholly government-led programmes.

\section{Conclusion}

The historic settlements of Saudi Arabia's Red Sea coast are at a critical point where a majority are threatened with an irrevocable loss of valuable cultural assets of local, regional and international significance. Following years of abandonment their preservation, and the social hierarchies, customs and skills that have been carried through many generations are in danger of not being passed onto future generations.

Although opportunities for the revitalisation of historic cores and traditional settlements as living environments are limited, it is possible to approach their regeneration in an imaginative and socially responsible manner. In a climate of limited local interest and the isolation of the built heritage means that tourism will become a primary player in their survival. Although this may create sterile settings possibly depicting an imagined past, it holds within it opportunities to conserve and re-use some buildings for a number of functions and to start generating interest in and recognition of these historic quarters. Tourism development in itself is not without challenges and the magnitude of the task ahead, a race against time with limited craft resources, is significant.

Building awareness and understanding of conservation amongst decision makers is an important first step, but a much bigger challenge lies in convincing the local population of the value of this heritage and encouraging them to take an active part in its renovation and re-use, as owners, users or as visitors. Like many studies have found, the dedication of a local community to a project is more likely to be successful than wholly government-led programmes. 